\title{
TRANSATLANTIC TRADE DISPUTES ON HEALTH, ENVIRONMENTAL AND ANIMAL WELFARE STANDARDS: BACKGROUND TO REGULATORY DIVERGENCE AND POSSIBLE SOLUTIONS
}

\begin{abstract}
Tamara Perišin*
Summary: The paper analyses the pattern and background of transatlantic trade disputes where the US and Canada have challenged EU health, environmental or animal welfare. It shows that, in principle, the EU maintains stricter (or arguably higher) standards in these areas, partly due to some historic events or societal characteristics which make Europeans more risk averse, and partly due to the nature of the EU supranational regulatory process. The paper examines whether and how the currently negotiated agreements, CETA and TTIP, could address this regulatory divergence. It argues that the regulatory differences which reflect the different values of two constituencies are worth maintaining so as to foster pluralism, diversity, experimentation and democracy. In contrast, regulatory differences caused by the mere fact that regulators work independently of one another should be eliminated so as to achieve the benefits of greater trade liberalisation.
\end{abstract}

\section{Introduction}

The European Union (EU), the United States (US) and Canada belong to the same cultural circle and subscribe to similar values. In principle, they are all interested in achieving a high level of protection of health, environment and animal welfare, and this is visible in their regulatory and deregulatory activities. However, particular trade disputes show different levels of commitment to a particular value and different levels of risk aversion. While regulatory differences were already visible in disputes which arose before the establishment of the World Trade Organization (WTO) in 1995 (such as Tuna/Dolphin where the EU challenged US rules on marine management ${ }^{1}$ ), since the establishment of the WTO the US and Canada have significantly more frequently challenged EU measures with high standards of protection than vice versa. The focus of this paper

\footnotetext{
Prof Tamara Perišin, MJur (Oxon), PhD, Faculty of Law, University of Zagreb. Thanks to Harvard Law School where part of this research was conducted within the postdoctoral visitors' programme; to Sam Koplewicz for his research assistance; and to the participants of the Harvard European Law Association lecture series for their valuable feedback.

1 GATT Panel Report, US - Restrictions on Imports of Tuna (3 September 1991) DS21/R 39S/155, unadopted; GATT Panel Report (16 June 1994) DS29/R, unadopted (hereinafter: Tuna/Dolphin I; I).
} 
is on the transatlantic trade disputes where the US or Canada has challenged EU measures entailing environmental, health or animal welfare (moral) standards.

This paper has three main parts. The first main part looks at the number and type of transatlantic trade disputes to show a pattern, and areas where the EU standards have been stricter. The second one inquires into the reasons behind regulatory divergence which leads to disputes against the EU. The third main part examines ways of addressing this regulatory divergence, including under the currently negotiated agreements, the Transatlantic Trade and Investment Partnership (TTIP) and the Comprehensive Economic and Trade Agreement (CETA). The paper argues that regulatory divergence which is a consequence of the true legitimate aims of different constituencies is one worth keeping so as to maintain a democratic system and to keep the advantages of diversity, pluralism and experimentation. In contrast, regulatory differences which are the mere accidental consequence of the fact that regulators work independently of one another should be eliminated to achieve the advantages of trade liberalisation. The method of removing non-tariff barriers to trade should be sensitive to the distinction between these two types regulatory diversity.

\section{Trade disputes challenging EU's strict health, environmental or animal welfare standards}

The number and substance of transatlantic trade disputes show that disputes initiated by the US or Canada against the EU are of a very different type from those going in the other direction. ${ }^{2}$ Disputes against the EU frequently entail challenges of a regulatory standard having a health, environmental or animal welfare aspect, while the same is never true of disputes which the EU starts against the US or Canada.

First, concerning EU - US trade disputes, since the establishment of the WTO there has been a total of 51 trade dispute, but many have never reached the stage of Panel proceedings so they are not of interest to this paper. Some 32 disputes were initiated by the EU against the US, and 15 of those reached the Panel report (14 were appealed so they reached the Appellate Body $(\mathrm{AB})$ report). A total of 19 disputes were initiated by the US against the EU, and 8 of those reached the Panel report (4 went up on appeal and led to an $\mathrm{AB}$ report).

2 For an overview of all disputes see, WTO, Map of Disputes Between WTO Members $<$ http://www.wto.org/english/tratop_e/dispu_e/dispu_maps_e.htm?country selected=EEC\&sense=e $>$ accessed 28 June 2014 . 
More interesting than the number of these cases is their substance. Namely, cases brought by the EU against the US mostly concerned antidumping, subsidies, intellectual property, and there were no cases where the EU challenged a US high regulatory standard on the basis of the TBT or SPS agreements (even Art III:4 GATT was never the cornerstone of an EU claim, but was merely mentioned alongside other claims which were more relevant for particular cases). In contrast, among the decided cases brought by the US against the EU, there were two complaints, EC - Hormones ${ }^{3}$ and EC - Biotech, ${ }^{4}$ that argued that an EU regulatory standard was, inter alia, contrary to the SPS and TBT. In EC-Hormones, the object of the attack was the EU ban of meat and meat products derived from cattle which, for growth promotion purposes, had been treated with certain natural or synthetic hormones. In EC-Biotech, the challenge was directed against EU rules on genetically modified organisms. The EU lost both cases as its measures were found to be contrary to the SPS.

There is another pending case, EC - Poultry, where the US is challenging an EU regulatory standard as contrary to the TBT and SPA. ${ }^{5}$ The case concerns the EU ban on poultry meat treated with certain chemical substances used in the US. A Panel was established, but not yet composed.

Second, concerning EU - Canada trade disputes, there has been a total of 15 disputes, again several not reaching the stage of Panel proceedings. A total of 6 disputes were initiated by the EU against Canada, and 4 of those reached the stage of a Panel report (and 3 led to an AB report). Some 9 disputes were initiated by Canada against the EU, and 4 of those were decided by the WTO dispute settlement bodies leading to 4 Panel reports (and 3 to $\mathrm{AB}$ reports).

Again, if one looks at the substance of the decided disputes, one will see that the EU challenged Canadian measures on the basis of the subsidies agreement, TRIPS, TRIMs etc, but there has been no case where it challenged a regulatory standard in the field of health, environment or animal welfare. By contrast, all of the disputes that Canada initiated against the EU, EC-Hormones, EC-Asbestos, ${ }^{6}$ EC - Biotech and EC Seals, ${ }^{7}$ entailed a challenge of a regulatory standard concerning health,

\footnotetext{
3 WTO, EC-Measures Concerning Meat and Meat Products (Hormones), Report of the Appellate Body (16 January 1998) WT/DS26/AB/R and WT/DS48/AB/R.

4 WTO, EC - Measures Affecting the Approval and Marketing of Biotech Products, Panel Reports (29 September 2006) WT/DS291-293/R.

5 WTO, EC - Certain Measures Affecting Poultry Meat and Poultry Meat Products from the US, Request for Consultations by the US (20 January 2009) WT/DS389/1.

6 WTO, EC-Measures Affecting Asbestos and Asbestos-Containing Products, Report of the Appellate Body (12 March 2001), WT/DS135/AB/R.

7 WTO, EC - Measures Prohibiting the Importation and Marketing of Seal Products, Report of the Appellate Body (22 May 2014) WT/DS400\&401/AB/R.
} 
environment or animal welfare, which Canada saw as contrary to the GATT, TBT and/or SPS. In EC-Hormones and EC - Biotech, Canada's complaint was parallel to those of the US (above) dealing with rules on beef-hormones and GMOs, respectively. In EC-Asbestos, Canada challenged an EU Member State decree prohibiting the manufacture, sale, import, export, transfer, etc of all asbestos fibres and of all asbestos products. And most recently, in EC-Seals, Canada challenged the EU ban on seal products. The EU was found to be in breach of WTO in all of these cases, except in EC-Asbestos.

There is also a number of transatlantic trade disputes that arose outside the WTO, in other international and supranational fora, and that could reach the WTO dispute settlement process at some stage. For example, a WTO dispute could arise concerning EU rules on aviation emissions. ${ }^{8}$ Several years ago, a number of US airline companies decided to take to the European Court of Justice (ECJ) a case against the EU Aviation Emissions Directive aimed at environmental protection by requiring the purchase of emissions allowances for all flights to and from the EU (including for emissions which do not occur over EU territory, but instead over, for example, US territory or the open seas). ${ }^{9}$ These companies lost the case, but they have continued exerting pressure on their government to resolve the issue in other available fora, such as the International Civil Aviation Organization (ICAO) ${ }^{10}$ or the WTO. ${ }^{11}$ Similarly, battles for a regulatory standard are happening with the Codex Alimentarius Commission. The most striking example concerns the additive, ractopamine. The EU bans the use of ractopamine as animal feed, and bans meat containing its residues, while this additive is in common use in the US and Canada. Despite the EU's opposition, the Codex Alimentarius Commission approved minimal residues of this substance in meat, with a controversial vote of 69-67, and 7 abstentions. ${ }^{12}$

8 Directive 2008/101/EC of the European Parliament and of the Council of 19 November 2008 amending Directive 2003/87/EC so as to include aviation activities in the scheme for greenhouse gas emission allowance trading within the Community [2009] OJ L8/3.

9 Case C-366/10 Air Transport Association of America v Secretary of State for Energy and Climate Change, judgment of 21 December 2011.

10 An agreement was reached at the last ICAO General Assembly that the ICAO would start developing a global system of market-based measures. ICAO Resolution A38-18: Consolidated statement of continuing ICAO policies and practices related to environmental protection - Climate change, November 2013, particularly Art 19.

11 International Centre for Trade and Sustainable Development, 'EU Aviation Emissions Levy Ruled Lawful by European Court as Measure Enters into Force' (2011) 16(1) Bridges Weekly Trade News Digest <http://ictsd.org/i/news/bridgesweekly/123063/> accessed 28 June 2014.

12 EU Press Release Database, 'Codex Alimentarius: Statement by the EU on Ractopamine', News from the European Commission's Midday Briefing <europa.eu/rapid/middayexpress-06-07-2012.htm> accessed 3 April 2014; A Alemanno and G Capodieci, 'Testing the Limits of Global Food Governance: The Case of Ractopamine' (2012) 3 European Journal of Risk Regulation <ssrn.com/abstract=2133908> accessed 3 April 2014. 
Similar cases concerning the EU's comparatively stricter standards frequently appear on the horizon, eg those concerning meat of the offspring of cloned animals, ${ }^{13}$ apples treated with DPA to prevent storage scald, ${ }^{14}$ nano-ingredients in foods, ${ }^{15}$ etc. Some of those might get addressed through the diplomatic, political process and others might lead to judicial disputes.

\section{Reasons for regulatory divergence}

As a general rule, regulatory divergence happens as an incidental consequence of the fact that regulators in different countries work independently of each other so they come up with different regulatory solutions. In most cases, regulatory divergence is not a consequence of entrenched values or different views, but is merely accidental. However, a pattern of disputes between the EU, on the one hand, and the US and Canada, on the other hand, shows that their regulatory differences in the field of health, environmental and animal welfare are not accidental, but that the EU has a policy of adopting relatively stricter standards than the US or Canada. There are two possible groups of reasons for this: the first are connected to European society and history, and the second are connected to the specific regulatory process in the EU as a supranational organisation.

\subsection{Societal and historic reasons}

Societies and values are formed over centuries, but it can also take only one important event to change them. It is sometimes argued that the long history of the European continent makes Europeans more reliant on tradition. ${ }^{16}$ There are indeed some examples of this. In the area of food

\footnotetext{
13 European Parliament, 'EU Countries Reject EP Call for Labelling of Clone-derived Food', 29 March 2011 <www.europarl.europa.eu/sides/getDoc.do?type=IM-PRESS\&reference=20 1 10324STO16430\&secondRef $=0 \&$ language $=E N>$ accessed 3 April 2014; European Parliament News, 'Parliament issues urgent call to regulate cloned foods' 11 May $2011<w w w$. europarl.europa.eu/news/en/pressroom/content/20110506IPR18894/html/Parliamentissues-urgent-call-to-regulate-cloned-foods > accessed 3 April 2014; Council of the EU, 'Novel Foods: Statement of the Council's Legal Service' 17 May 2011, 10332/11, PRESSE 140 <www.consilium.europa.eu/uedocs/cms_data/docs/pressdata/en/lsa/122071.pdf> accessed 3 April 2014.

14 Tom Philpott, 'American Apples Just Got Banned in Europe' (24 April 2014) Mother Jones <http://www.motherjones.com/tom-philpott/2014/04/europe-just-banned-applesyou-eat> accessed 28 June 2014.

15 Euractiv, 'Parliament Rejects Draft EU Law Allowing Nanomaterials in Food', 12 March 2014 <www.euractiv.com/health/parliament-opposes-commission-na-news-534093> accessed 3 April 2014.

16 Marsha A Echols 'Food Safety Regulation in the European Union and the United States: Different Cultures, Different Laws' (1998) 4 Columbia Journal of European Law 525, 528; David Vogel, The Hare and the Tortoise Revisited: The New Politics of Consumer and Environmental Regulation in Europe' (2003) 33 British Journal of Political Science 557, 562.
} 
standards, Europeans consider many traditional types of food production as safe, and even especially endorse it while Americans fear them. In Europe, the 'safety [of traditional food products] is assumed based on centuries of experience rather than on laboratory science'. ${ }^{17}$ For example, the use of unpasteurised milk in food production is explicitly permitted in EU legislation ${ }^{18}$ and several unpasteurised cheeses such as Brie, Camembert, Roquefort, Feta, etc, are even seen as champions of European quality, having the protected designation of origin. ${ }^{19}$ In the US, cheese made with unpasteurised milk is seen as unsafe ${ }^{20}$ and is prohibited unless it has been aged for 60 days. ${ }^{21}$ In contrast, European consumers are reluctant to accept the new technologies of producing foods. Eurobarometer reports show that Europeans are worried about hormone residues in meats, ${ }^{22}$ genetically modified foods, ${ }^{23}$ the meat of cloned animals ${ }^{24}$, and the majority have never heard of nanotechnology. ${ }^{25}$ Their concerns are reflected in strict regulation. In contrast, in the US some opinion polls do show concerns about these food productions, ${ }^{26}$ but these have not been reflected in regulation.

17 Echols (n 16) 528.

18 Council Directive 92/46/EEC of 16 June 1992 laying down the health rules for the production and placing on the market of raw milk, heat-treated milk and milk-based products [1992] OJ L268/1; Council Directive 94/71/EC of 13 December 1994 amending Directive 92/46/EEC laying down the health rules for the production and placing on the market of raw milk, heat- treated milk and milk-based products [1994] OJ L368/33. See on this point Echols (n 16) 530-533.

19 For a list of protected designations of origin, geographical indications and guaranteed traditional specialties, see EU Database of Origin and Registration (DOOR) <http:// ec.europa.eu/agriculture/quality/door/list.html> accessed 28 June 2014.

20 US Food and Drug Administration, 'The Dangers of Raw Milk: Unpasteurized Milk Can Pose a Serious Health Risk' <http://www.fda.gov/downloads/Food/FoodborneIllnessContaminants/UCM239493.pdf> accessed 28 June 2014.

${ }^{21}$ US Food and Drug Administration, Code of Federal Regulations, 21 CFR Sec 1240.61 'Mandatory pasteurization for all milk and milk products in final package form intended for direct human consumption' (Revised 1 April 2014); Code of Federal Regulations, 7 CFR 58.439 Cheese from unpasteurized milk! January 2004).

22 Commission, Special Eurobarometer, Risk Issues (2006) 20.

23 ibid 24.

${ }^{24}$ Commission, Flash Eurobarometer, Europeans' Attitudes towards Animal Cloning, Analytical Report (2008) 20.

25 Commission, Special Eurobarometer, Biotechnology Report (2010) 33.

26 Eg American concerns about hormones and GMOs have been recorded in Yun-Jae Hwang, Brian Roe, Mario F Teisl, 'An Empirical Analysis of United States Consumers' Concerns About Eight Food Production and Processing Technologies' (2005) 8(1) AgBioForum - The Journal of Agrobiotechnology Management \& Economics, Article $6<$ http:/ /www.agbioforum.org/v8n1/v8n1a06-roe.htm> accessed 28 June 2014; similarly, American concerns about GMOs were also shown on ABC News, 'Poll: Skepticism of Genetically Modified Foods' (19 June 2013) <http://abcnews.go.com/Technology/story?id=97567> accessed 15 July 2014. 
However, even more than the centuries of tradition, risk regulation is influenced by more recent events. This phenomenon where knowledge about a recent hazard significantly influences behaviour is what psychology and behavioural law and economics refer to as 'availability of information' ${ }^{27}$ There is extensive literature discussing how US regulatory standards in the 1960s until the 1980s were stricter than those in the EC. ${ }^{28}$ The tables turned in the 1990s when a number of scandals shook Europe, (arguably) ${ }^{29}$ making Europeans more aware and cautious about the risks arising from new technologies, not only in food but in other areas as well. ${ }^{30}$ Particularly salient was the outbreak of the CreutzfeldtJakob disease caused by 'mad cows' that were infected through feed containing infectious meat and bone meal. ${ }^{31}$ The outbreak of this disease was also poorly managed. ${ }^{32}$ Relevant authorities and scientists alike not only failed to properly warn about this, but were also slow in admitting that there was a problem. This and similar scandals ${ }^{33}$ have made Europeans more doubtful about information that is presented as scientific fact, and more prone to relying on the precautionary principle. Europeans consider that it takes decades to determine whether a particular technology is safe, and are reluctant to accept its risks.

Such relatively recent incidents have shaped European attitudes not only towards food safety, but more broadly towards health, environment and animal welfare. For example, asbestos had been used for decades before its harmful properties were discovered. It is true that the harmful properties of asbestos affected not only Europe, but all countries where asbestos was used. However, the reaction in Europe, for example in France, was to ban asbestos, while Canada, for instance, merely started

\footnotetext{
${ }_{27}$ Richard H Thaler, Cass R Sunstein, Nudge: Improving Decisions about Health, Wealth, and Happiness (Yale University Press 2008); Christine Jolls, Cass R Sunstein and Richard Thaler, 'A Behavioral Approach to Law and Economics' (1998) 50 Stanford Law Review $1471,1518-1519$.

28 See eg Vogel (n 16). See also Pamela A Vesilind. 'Continental Drift: Agricultural Trade and the Widening Gap between the European Union and United States Animal Welfare Laws' (2010-11) 12 Vermont Journal of Environmental Law 223, 224-225 on recent food safety scandals in the US that triggered new legislation.

29 For an analysis showing that Europe is not more risk averse than the US, but that there are opposite examples which can be explained by the context in which a particular risk is observed, see Jonathan B Wiener and Michael D Rogers, 'Comparing Precaution in the United States and Europe' (2002) 5 Journal of Risk Research 317.

30 Katherine O'Neill, 'Mad Cows and Ailing Hens: The Transatlantic Relationship and Livestock Diseases' (2006) eScholarship, University of European Studies, Berkeley <http:// escholarship.org/uc/item/94f2963j> accessed 28 June 2014.

31 UK Department for Environment, Food and Rural Affairs, 'BSE: Disease Control \& Eradication - Causes of BSE' <http://webarchive.nationalarchives.gov.uk/20130123162956/http:/ www.defra.gov.uk/animalh/bse/controls-eradication/causes.html> accessed 28 June 2014.

32 O'Neill (n 30) 8.

33 See E Ragnar, DV Löfstedt and D Vogel, 'The Changing Character of Regulation: A Comparison of Europe and the United States' (2001) 21 Risk Analysis 399, 403.
} 
using it in a safer way, ${ }^{34}$ and the US first banned it, but then an appeals court struck the ban down ${ }^{35}$ so nowadays asbestos is not entirely prohibited in the US. ${ }^{36}$

Europeans are also quite concerned about the environment, and the risks posed to it by modern technologies and lifestyle. This has also been reflected in regulations. For example, European concerns about GMO crops which are not only relevant for human health, but also for environmental balance, have translated into restrictive rules. Similarly, Europeans are very worried about climate change, and rank it as the second most serious global problem, preceded only by 'poverty, hunger and lack of drinking water'. ${ }^{37}$ Europe has been relatively active in adopting measures addressing climate change, for example through its Emissions Trading System (ETS). In contrast, in the US there are still influential political actors (not only those in the margins) who deny the existence of climate change or that it is a consequence of human activity. ${ }^{38}$

Finally, Europeans have significant concerns about animal welfare, ${ }^{39}$ which has translated into a number of measures seeking to protect farmed animals through rules on farming, ${ }^{40}$ transport,${ }^{41}$ and slaughter. ${ }^{42}$ While these rules are mostly intended to regulate domestic production and transport, they still have external effects. For example, due to the

\footnotetext{
34 WTO, EC-Asbestos (n 6).

35 Warren E Leary, 'Appeals Court Strikes Down Major Parts of Federal Asbestos Ban' New York Times (New York 22 October 1991) <http:/ /www.nytimes.com/1991/10/22/us/appeals-court-strikes-down-major-parts-of-federal-asbestos-ban.html> accessed 28 June 2014. 36 See United States Environmental Protection Agency, 'Asbestos Laws and Regulations' <http://www2.epa.gov/asbestos/asbestos-laws-and-regulations> accessed 28 June 2014.

37 Commission, Special Eurobarometer 372, Climate Change Report (2011) 5-17.

38 See eg a speech by the Congressman Representative Paul Broun, Chairman of the Investigations and Oversight Subcommittee for the House Science, Space, and Technology Committee, available at <http://www.huffingtonpost.com/bill-moyers/watch-when-congressmen-de_b_4697151.html> accessed 28 June 2014; also Juliet Eilperin, 'Tea Party Republicans Are Biggest Climate Change Deniers, New Pew Poll Finds' Washington Post (Washington DC, 1 November 2013); Edward Maibach and others, 'A National Survey of Republicans and Republican-Leaning Independents on Energy and Climate Change' (April 2013) < http://environment.yale.edu/climate-communication/files/Republican_Views_on_ Climate_Change.pdf> accessed 28 June 2014.

39 Commission, Special Eurobarometer: Attitudes of EU Citizens Towards Animal Welfare, 2007; Commission, Attitudes of Consumers Towards the Welfare of Farmed Animals, Wave 2, 2007.

40 Eg Council Directive 98/58/EC of 20 July 1998 concerning the protection of animals kept for farming purposes [1998] OJ L221/23.

41 Eg Council Regulation (EC) 1/2005 of 22 December 2004 on the protection of animals during transport and related operations and amending Directives 64/432/EEC and 93/119/EC and Regulation (EC) 1255/97 [2005] OJ L3/1.

42 Eg Council Directive 93/119/EC of 22 December 1993 on the protection of animals at the time of slaughter or killing [1993] OJ L340/21.
} 
high standards for the farming and slaughter of poultry in the EU, ${ }^{43}$ poultry meat does not need to undergo any chemical treatment for removing bacteria, but is only rinsed with water before being placed on the market. EU production does not practise rinsing poultry carcases in substances such as chlorine dioxide, acidified sodium chlorite, trisodium phosphate, and peroxyacids, and the EU even considers that kind of practice to be harmful for human health. In contrast, these chemicals are in common use in the US as necessary for preventing the development of bacteria and ensuring food safety. ${ }^{44}$ The EU ban on the imports of poultry treated with such chemicals has triggered a trade dispute. Another external consequence of high standards of animal welfare is that EU farming is more expensive than that in countries with lower standards. ${ }^{45}$ In order to protect that expensive domestic production, the EU has not been willing to liberalise its agriculture and open its borders to cheap imports, holding back progress in the Doha Round of WTO negotiations.

The EU is often criticised on the other side of the Atlantic, as its strict standards in the field of health, environment and animal welfare are perceived as covert protectionism. Many believe that meat treated with hormones, GMOs or chlorinated poultry are just as safe as the counterparts of these products which are permitted in the EU. It is perceived that the EU authorities should do more to educate the public about the safety of the US or Canadian alternatives, and then opinion would be more favourable to such goods. Certainly, it would be condemnable if these 'values' were used for concealing protectionism, and the WTO Panel or $\mathrm{AB}$ could then determine a breach of obligations. However, in many of these European examples it is not clear that protectionism exists or even that educating the public could change European views. The fact that something does not cause an observable negative effect at this moment would often not satisfy EU citizens as it took decades for the effects of cow disease or of asbestos fibres on human health to become visible. Precaution is something that the EU authorities often rely on, but this should be done in accordance with the WTO rules which apply to this principle. ${ }^{46}$

\subsection{Regulatory process in the EU}

EU strict standards in the field of health, environment and animal welfare are also caused by the specificities of the EU regulatory process.

\footnotetext{
43 Council Directive 2007/43/EC of 28 June 2007 laying down minimum rules for the protection of chickens kept for meat production, [2007] OJ L182/19; Council Directive 1999/74/EC of 19 July 1999 laying down minimum standards for the protection of laying hens [1999] OJ L203/53.

44 See Vesilind (n 28) for a comment on the current state of animal welfare in food production in the US.

45 ibid 225-226.

46 See Art 5.7 SPS.
} 
Namely, it is frequently the case that the EU rule is much stricter than the average of Member State rules which existed prior to EU legislation. In fact, it is the often the strictest of all Member State rules that becomes the EU-wide rule. Basically, EU decision-making turns a 'regulatory peak' into the EU norm. There are several aspects of EU decision-making that bring this about.

First, the EU Treaties require the EU to ensure high levels of health, safety, environmental protection, animal welfare consumer protection, etc, when adopting common rules. ${ }^{47}$ Internal market measures are the best examples of how far the EU goes in ensuring these values. Namely, Art 114 TFEU provides a legal basis for measures aimed at the establishment and functioning of the internal market. In Tobacco Advertising, the Court held that these measures must contribute to the elimination of obstacles to the free movement of goods or services or to the removal of appreciable distortions of competition. ${ }^{48}$ However, once the conditions for recourse to this legal basis are met, the EU institutions are allowed and even required to regulate not only at the minimal level to remove these market problems, but at a level which ensures the high protection of other values. ${ }^{49}$ The Court has been very permissive in allowing such strict measures. It has even supported measures which caused even worse obstacles to free movement than originally existed without EU legislation. Prime examples of this are the BAT case supporting strict tobacco labelling rules that prevent a pack of cigarettes from moving between (typically) more than two Member States; ${ }^{50}$ and Swedish Match allowing the ban of snus. ${ }^{51}$ Similar is the example of the EU ban of seal products which was also adopted on the basis of Art 114 TFEU. ${ }^{52}$ This ban was challenged before the ECJ, but the Court did not go into the merits of

\footnotetext{
47 Arts 114(3), 13, 168, 169, 191 TFEU.

48 Case C-376/98 Germany $v$ European Parliament \& Council [2000] ECR I-8419 (hereinafter: Tobacco Advertising).

49 ibid para 88.

50 Case C-491/01 The Queen and Secretary of State for Health, ex parte: British American Tobacco Investments Ltd and Imperial Tobacco Ltd, supported by Japan Tobacco Inc. and JT International SA [2002] ECR I-11453. The size of the mandatory warnings on packages (general warning having to occupy a minimum of $30 \%$ of the most visible surface of the unit packet, and the additional warning a minimum of $40 \%$ on the other most visible side of the packet) and the requirement that the warnings have to be in the official language makes it impossible to create a packet with warnings in more than two languages. Consequently, each pack has a limited freedom of movement just to states where those languages are the official ones. See on this, DA Wyatt and AA Dashwood, European Union Law $\left(5^{\text {th }}\right.$ edn, Sweet and Maxwell, 2006) 944-952.

51 Case C-210/03 Swedish Match AB and Swedish Match UK Ltd v. Secretary of State for Health [2004] ECR I-11893.

52 Regulation (EC) 1007/2009 of the European Parliament and of the Council of 16 September 2009 on trade in seal products [2009] OJ L286/36.
} 
the case as it found the action inadmissible. ${ }^{53}$ The ban did lead to a WTO dispute, and the EU is required to amend its measure. ${ }^{54}$

Second, very restrictive common rules can be a consequence of the dynamics of decision-making within the Council. It might often be the case that a State with more stringent rules can frequently have a better bargaining position within the Council than States with lower standards. Namely, '[s]o long as there is no agreement, its industry is protected from foreign competition, while those of its trading partners are hurt by being denied access to the market'. ${ }^{55}$ The strength of a Member State's bargaining position in the Council will depend on the voting rules and on whether its products will be competitive in other States, bearing in mind their possibly higher price caused by compliance to higher standards.

Third, the European Parliament is frequently an important factor in pushing for a high level of protection of certain non-trade objectives. ${ }^{56}$ The Parliament understands that strict rules lead to obstacles to external trade and fewer trade liberalisation benefits, but it frequently does not give that much value. ${ }^{57}$ In many instances leading to international trade disputes, it was the Parliament that was the main supporter of a measure that became challenged and even found to be in breach of WTO law. For example, in the dispute concerning beef treated with growth hormones, the Commission wanted to amend EU legislation to make it less restrictive and WTO compatible, but it was the Parliament that was against it. ${ }^{58}$ Similarly, the Commission had not proposed a total ban of seal products, but merely a conditional one which would allow on the EU market seal products harvested in a humane way and properly labelled, ${ }^{59}$ but this was amended by the Parliament, turning the measure into a total ban

53 Case C-583/11 P Inuit Tapiriit Kanatami and Others $v$ Parliament and Council, judgment of 3 October 2013.

54 WTO, EC - Seal Products (n 7).

55 AR Young, 'Incidental Fortress: The Single European Market and the World Trade' (2004) 42(2) Journal of Common Market Studies 393, 401, 410.

56 See T Perišin, EU Regulatory Policy and World Trade: Should All EU Institutions Care What the World Thinks? (forthcoming).

57 See eg the Parliament's reasoning on WTO law in 'I Report on the proposal for a European Parliament and Council directive amending for the seventh time Council Directive $76 / 768 / \mathrm{EEC}$ on the approximation of the laws of the Member States relating to cosmetic products' (COM(2000) 189 - C5-0244/2000 - 2000/0077(COD)) Committee on the Environment, Public Health and Consumer Policy, FINAL A5-0095/2001, 21 March 2001.

58 After the Lamming scientific report that found the use of three relevant natural hormones for growth promotion purposes not to be harmful and that additional tests were needed concerning the safety of two synthetic hormones, the Commission proposed a new directive which followed such an approach. WTO, EC-Measures Concerning Meat and Meat Products (Hormones) - Complainant: US, Panel Report (18 August 1997) WT/DS26/R/USA, paras II 28-29.

59 Proposal for a Regulation of the European Parliament and of the Council concerning trade in seals products, 2008/0160 (COD). 
(with two narrow exceptions) which were later challenged both within the EU and in the WTO. ${ }^{60}$ In the case of the Aviation Emissions Directive, it was also the Parliament that most strongly opposed a postponement of the application of the Directive to flights to and from the EU. ${ }^{61}$ The Parliament was also the proponent of not allowing nano-technology in food, ${ }^{62}$ etc. One might argue that these are populist measures responding to some concerns of EU voters who are not necessarily informed about all the pros and cons of the measure at issue. Zigler argued on this point that the regulatory difference between the EU and the US also arises as a consequence of the fact that the regulation of health, environment and animal welfare in the EU is in the hands of politicians, and in the US it is mostly done by regulatory agencies such as the Food and Drug Administration (FDA) or the Environmental Protection Agency (EPA). ${ }^{63}$

Fourth, the EU is aware that it can export its health, environmental or animal welfare standard. While these standards are primarily adopted to serve an internal policy, they have incidental external effects which can trigger the export of standards (the 'Brussels effect'64). There are three main ways in which the export of standards can occur. One is de facto when producers in third countries start complying with such EU standards. This has happened with EU standards on beef hormones. The EU lost the case in the WTO, but it has not abandoned its measure. The long-term effect after many years was that the US and Canadian farmers adjusted their production and gained better conditions for imports of 'high quality beef' into the EU. ${ }^{65}$ The second type of export of stand-

60 For an overview of the Seal Products Regulation's legislative history, see Ferdi de Ville, 'Explaining the Genesis of a Trade Dispute: The European Union's Seal Trade Ban' (2012) 34 Journal of European Integration 37.

61 EurActiv, 'MEPs Defy EU States on Aviation Emissions Law' (31 January 2014) <www. euractiv.com/transport/parliament-defies-european-counc-news-533156> accessed 3 April 2014; EurActiv, 'Kallas: Global Aviation Emissions Talks "A Nightmare" (7 March 2014) <www.euractiv.com/transport/kallas-calls-global-talks-aviati-news-533967> accessed 3 April 2014, citing German MEP Pieter Liese.

62 Euractiv (n 15).

63 Oliver Ziegler, 'EU-US Regulatory Coordination. A Two-level Game Approach' (2009) FRP Working Paper 04/09, 5 <http://www.regensburger-politikwissenschaftler.de/frp_working_paper_04_2009.pdf> accessed 28 June 2014.

64 Marise Cremona, 'The Single Market as a Global Export Brand' (2010) 21 EBL Rev 663; Anu Bradford, 'The Brussels Effect' (2012) 107 NWUL Rev 1; Chad Damro, 'Market Power Europe' (2012) 19 Journal of European Public Policy 682; Joanne Scott, 'Extraterritoriality and Territorial Extension in EU Law' (2014) 62 AJCL 87; Alasdair R Young, 'Europe As a Global Regulator? The Limits of EU Influence in International Food Safety Standards' (2014) 21 Journal of European Public Policy 904; Sandra Lavenex, 'The Power of Functionalist Extension: How EU Rules Travel' (2014) 21 Journal of European Public Policy 885.

65 Memoranda of Understanding between the United States of America / Canada and the European Commission Regarding the Importation of Beef from Animals Not Treated with Certain Growth-Promoting Hormones and Increased Duties Applied by the United States to Certain Products of the EC, WT/DS26/28, 30 September 2009 / WT/DS48/26, 22 March 
ards occurs when third countries follow the EU model and adopt similar rules (de iure export at national levels). For example, the Seal Products Regulation was accompanied by this type of export of standards in the sense that the EU led by example, and several other countries followed suit. ${ }^{66}$ The third type of export happens when a global standard-setting body adopts the EU standard as its own (de iure export at international level). The example of this might be rules on aviation emissions if the EU standard (or a standard close to it) are adopted at the international level within the International Civil Aviation Organization. The EU rule (which is temporarily suspended) would require all flights to and from the EU to pay allowances for the emissions released on the entire flight. Under the pressure of that measure being applied to non-EU aircrafts, the last ICAO General Assembly agreed that the ICAO would start developing a global system of market-based measures so as to make a decision on it at its next meeting in 2016, and implementation should start in $2020 .{ }^{67}$

\section{Addressing regulatory diversion}

Regulatory divergence presents a trade barrier, regardless of the fact whether different national laws are lawful or not. Thus, regulatory divergence is positive only if this is a reflection of the different interests or values of its constituencies. In most cases, however, regulatory divergence does not occur because people of different constituencies have different priorities, but merely because their respective regulators do not communicate when setting standards. For example, car manufacturers are unable to produce a 'world car' ie a vehicle that could be marketed without any change all over the world, and this is not only because of differing consumer preferences, but because of accidental regulatory divergence. Two large automobile markets, the EU and the US, have different rules on the emission of carbon monoxide, nitrogen oxides and other greenhouse gasses, some being stricter on one side of the Atlantic, and some on the other. ${ }^{68}$

\footnotetext{
2011; Regulation (EU) No 464/2012 of the European Parliament and of the Council of 22 May 2012 amending Council Regulation (EC) No 617/2009 opening an autonomous tariff quota for imports of high-quality beef [2012] OJ L 149/1.

66 Pravda, 'Russia Bans Harp Seal Trade. Next Stop, Canada!' <english.pravda.ru/opinion/ columnists/21-12-2011/120030-russia_seals-0/> accessed 3 April 2014.

67 ICAO Resolution A38-18: Consolidated statement of continuing ICAO policies and practices related to environmental protection - Climate change (November 2013), particularly Art 19.

68 For EU standards on pollutant emissions from light vehicles, see <http://europa.eu/ legislation_summaries/environment/air_pollution/128186_en.htm>; for US standards on these emissions see <http://www.epa.gov/otaq/standards/light-duty/> both accessed 28 June 2014.
} 
Over the last couple of decades, there has been a lot of effort and a number of agreements aimed at removing regulatory differences on the two sides of the Atlantic. Some of the effort to remove regulatory trade barriers is happening with the WTO, eg through the SPS committee where each member has to notify other members of a planned SPS measure, and these other WTO members have a chance to voice their positions. ${ }^{69}$ There is also a number of bilateral instruments which seek to serve this purpose. The EU and the US have in force the Transatlantic Economic Partnership ${ }^{70}$ which is accompanied by documents such as the Guidelines on Regulatory Cooperation and Transparency, ${ }^{71}$ and the institutional mechanism of the Transatlantic Economic Council and a number of other soft mechanisms for promoting regulatory convergence. ${ }^{72}$ Similarly, the EU and Canada have adopted a Framework on Regulatory Cooperation and Transparency ${ }^{73}$ promoting voluntary regulatory cooperation, as well as some sectoral agreements. ${ }^{74}$

Most recently, there has been an agenda of removing obstacles to transatlantic trade arising from regulatory divergence through more extensive trade agreements. The EU and Canada are at an advanced stage of negotiating the Comprehensive Economic and Trade Agreement. ${ }^{75}$ And in 2013, the EU and the US started negotiations on the Transatlantic Trade and Investment Partnership. Most documents concerning these agreements are kept confidential, ${ }^{76}$ but we do know that the elimination

${ }^{69}$ Art 7 and Annex B SPS; J Scott, The WTO Agreement on Sanitary and Phytosanitary Measures (Oxford University Press 2007) 57-58.

70 Transatlantic Economic Partnership, <ec.europa.eu/enterprise/policies/international/ files/trans_econ_partner_11_98_en.pdf> accessed 3 April 2014.

71 Guidelines on Regulatory Cooperation and Transparency, <ec.europa.eu/enterprise/ policies/international/files/guidelines3_en.pdf> accessed 3 April 2014.

72 Eg one of the first efforts in this respect was the Joint US-EU Statement on Early Warning and Problem Prevention Principles and Mechanisms, adopted in 1999. See <http:// ec.europa.eu/enterprise/policies/international/cooperating-governments/usa/regulatorycooperation/index_en.htm> accessed 28 June 2014.

${ }^{73}$ Government of Canada - European Commission Framework on Regulatory Co-Operation and Transparency <http://ec.europa.eu/enterprise/policies/international/files/ f1994_en.pdf> accessed 28 June 2014.

${ }^{74}$ Eg Veterinary Equivalence Agreement - Agreement between the European Community and the Government of Canada on sanitary measures to protect public and animal health in respect of trade in live animals and animal products [1999] OJ L71/3.

75 On CETA, see James Mathis, 'Multilateral Aspects of Advanced Regulatory Cooperation: Considerations for a Canada-EU Comprehensive Trade Agreement (CETA)' (2012) 39 Legal Issues of Economic Integration 73, 77; Stanko S Krstic, 'Regulatory Cooperation to Remove Non-tariff Barriers to Trade in Products: Key Challenges and Opportunities for the CanadaEU Comprehensive Trade Agreement (CETA)' (2012) 39 Legal Issues of Economic Integration 3.

76 Documents relating to the negotiation of international agreements might become more accessible following the recent ruling of the CJEU where it upheld a decision of the General Court stating that the Council erred in denying a Member of the European Parliament access to a document connected to an international agreement. C-350/12 $\mathrm{P}$ Council $v$ 
of non-tariff barriers to trade arising from regulatory divergence is on the agenda of both negotiations. There are two main issues here.

On the one hand, there is the question of which regulatory differences should be removed and which should be respected as arising from true differences in the legitimate aims of two polities. It would not be difficult to achieve political support for the elimination of trade barriers in cases where regulatory divergence is a mere consequence of the independent work of regulatory bodies in the sense that their rules achieve the same aims, but as no consultations have taken place, the way of achieving this aim is different. Most regulatory divergence is of this type. EU Trade Commissioner De Gucht stated that if one take[s] a broader view on regulatory issues[, the EU and the US] want the same thing in the end: a high level of protection for our people from risks to their health, safety, financial security and environment', and he argued that, for example, while seatbelts in the EU and the US might be differently regulated, they are equally safe. ${ }^{77}$ In contrast, different rules on GMOs are not accidental, but the EU sees them as pursuing legitimate aims and does not seem willing to remove them despite possible advantages if it did so for consumer choice (as there certainly would be consumers who would opt for a cheaper product regardless of its genetic properties). Some have argued that the TTIP will not be adopted if it sets a too ambitious goal, such as the removal of such trade barriers. Lester has argued that the TTIP only stands a chance of being adopted if it concentrates solely on 'low-hanging fruit'. ${ }^{78}$ However, there are political actors who consider that without addressing this barrier to the movement of GMOs, the US should drop the whole agreement. Max Bauchus, a Democrat, who was at the time a US senator from Montana, an agricultural state, wrote in the Financial Times that the US Congress should not support the agreement if the EU did not remove obstacles to the exports of US GM crops, and beef and pork fed with additives currently banned in the EU. ${ }^{79}$

In 't Veld, judgment of 3 July 2014; Euractiv, 'Les documents du TTIP peuvent être publiés, selon la Cour de justice européenne' (4 July 2014) < http://www.euractiv.fr/sections / euro-finances/les-documents-du-ttip-peuvent-etre-publies-selon-la-cour-de-justice?utm_ source=EurActiv + Newsletter\&utm_campaign=a270e62653-newsletter_derni\%C3\%A8res_ infos\&utm_medium $=$ email\&utm_term=0_da6c5d4235-a270e62653-55406953 > accessed 4 July 2014.

77 Karel De Gucht, 'A European Perspective on Transatlantic Free Trade' (Speech at the European Conference at Harvard Kennedy School: Europe 2.0: Taking the Next Step, Cambridge, USA, 2 March 2013) <http://europa.eu/rapid/press-release_SPEECH-13-178_ en.htm> accessed 15 July 2014.

78 Simon Lester and Inu Barbee, The Challenge of Cooperation: Regulatory Trade Barriers in the Transatlantic Trade and Investment Partnership' (2013) 16 Journal of International Economic Law 847, 849.

79 Max Baucus, 'Transatlantic Trade Deal Is a US priority' Financial Times (London, 4 March 2013). 
On the other hand, the question is how to remove the non-tariff barriers, ie through which mechanism. There is a number of theoretical possibilities, ranging from negative integration, ie deregulation requiring countries not to apply their standards to imports, to positive integration, ie reregulation where common rules would be set. The TTIP has been criticised, among other things, because it is based on an economic analysis which calculates the benefits for both markets arising from the elimination of non-tariff trade barriers without addressing how that is to be achieved ${ }^{80} \mathrm{CETA}$ is also not clear on that point, although official documents explicitly refer to recognition in some areas such as automotive standards and qualifications. ${ }^{81}$ It is thus worth examining the theoretically available possibilities.

The first option is the conditional mutual recognition of standards, such as the ones that exist in the EU between Member States. Within the EU, this type of mutual recognition requires any product lawfully produced and marketed in one Member State to be allowed in another Member State unless there is a justified reason for denying market access. The national regulatory autonomy of each member is limited in a way that a member can only exceptionally require foreign products to comply with its own standards. This is broader than the requirement of equivalence which already exists in the WTO concerning SPS standards and is encouraged by the TBT. ${ }^{82}$ Equivalence is a

case-based... finding that the home or exporting country regulation is equivalent - in the sense of satisfying the regulatory goal to the host or importing country regulation. Mutual recognition, on the other hand, involves broad and automatic recognition of foreign regulation, without case-based evaluation. ${ }^{83}$

Such a mechanism of removing trade barriers is politically acceptable only in a very homogeneous setting and/or if the general aims of the agreement are very ambitious (eg economic and social cohesion in Europe, peace, etc). The North Atlantic sphere is quite homogeneous in

\footnotetext{
80 See Ferdi De Ville and Gabriel Siles-Brügge, The EU-US Transatlantic Trade and Investment Partnership and the Role of Trade Impact Assessments: Managing Fictional Expectations' (Paper presented at the 55 ${ }^{\text {th }}$ International Studies Association Annual Convention, Toronto, 26-29 March, 2014).

81 Commission, 'Memo: Facts and Figures of the EU-Canada Free Trade Deal' (18 October 2013) <http://europa.eu/rapid/press-release_MEMO-13-911_en.htm> accessed 15 July 2014.

82 Art 4 SPS; Art 2.7 TBT.

83 JP Trachtman, 'Embedding Mutual Recognition at the WTO' (2007) 14 Journal of European Public Policy 780, 784. See also JHH Weiler, 'Mutual Recognition, Functional Equivalence and Harmonization in the Evolution of the European Common Market and the WTO' in F Kostoris Padoa Schioppa (ed), The Principle of Mutual Recognition in the European Integration Process (Palgrave 2005).
} 
comparison to the rest of the world, but there is a question of political feasibility whether the parties could aim for the elimination of the remaining differences in this way. Many fear that mutual recognition of standards would lead to the downgrading of standards. ${ }^{84}$ However, in arguing that point, it is often forgotten that mutual recognition of this type is conditional, ie that each country can prevent market access for imported goods if it has a legitimate aim and if it is pursuing that aim in a proportionate manner. Of course, the question here arises as to who would be the arbiter on whether an aim is a legitimate one, and whether the measure is proportionate (and what type of proportionality analysis is required). But even in the absence of any arbiter, one would expect that both trading partners would be aware that if they started invoking the exception recklessly, the other party would start doing the same and this would hurt both economies and undermine the entire agreement. It is theoretically possible that regulatory competition would work in the way that each trading partner would want to have less strict standards so as to keep production on its territory. However, that depends on whether a product complying with the higher standard would still be competitive on the market. The EU's example of regulating non-elastic markets, ie goods that can be placed on the market, instead of regulating production has proven successful in this respect. A producer wishing to place his products on the EU market has to conform to its standards regardless of where the production takes place. There is thus no incentive to move production elsewhere so as to avoid compliance with the EU standard. The EU has even managed in a number of cases to export its strict standards to other countries, frequently just de facto because foreign producers have adjusted their production to the EU standards (the 'Brussels effect'). ${ }^{85}$

The second theoretical option is a less intrusive type of mutual recognition where countries do not recognise each other's standards, but their conformity assessment procedures. This type of mutual recognition is already quite apparent on a global scale. WTO law requires members to

ensure, whenever possible, that results of conformity assessment procedures in other Members are accepted, even when those procedures differ from their own, provided they are satisfied that those procedures offer an assurance of conformity with applicable technical regulations or standards equivalent to their own procedures. ${ }^{86}$

WTO law also stimulates Member States to conclude agreements on mutual recognition of the results of their conformity assessment proce-

\footnotetext{
84 See De Ville and Gabriel Siles-Brügge (n 80) 2.

85 Bradford (n 64).

86 Art 6.1 TBT.
} 
dures (MRAs), ${ }^{87}$ and many countries have done so. However, as Mathis explains, initial enthusiasm about the trade liberalising potential of this instrument which existed after the WTO was set up quickly subsided:88

The painstaking process of certifying conformity assessment bodies across product sectors - one product and sector at a time - tended to demonstrate that the MRA mechanism was too cumbersome and too slow to achieve the kind of recognition results sought by the economic actors who understand how product standards and testing procedures functioned as non-tariff barriers in their important markets. ${ }^{89}$

Thus, the new comprehensive trade agreements, such as those between the EU and Canada, or between the EU and the US, will certainly aim to go beyond this type of MRA.

The third option is some sort of harmonisation by setting common standards. WTO law provides for some 'building up' in the sense that it encourages international standardisation. However, true harmonisation where common rules replace previously existing national rules requires a complex institutional set-up, either in the form of common institutions (as those that exist at the EU level) or intensive and continuous cooperation between two regulators (such as that which occurs, for example, in an EU candidate country before EU accession through the cooperation of the candidate country's and EU institutions). The first option of creating common institutions does not seem a probable agenda for a bilateral trade agreement. The second option of envisaging closer cooperation between domestic regulators is more likely. However, if each of the parties had a larger number of such bilateral agreements where its domestic institutions were required to work closely with those of its trading partners, the system would be difficult to maintain. ${ }^{90}$

It is also possible that the agreements could have a sectoral approach so that different methods of removing trade barriers would be used in different areas. For example, the EU TTIP negotiating position for motor vehicles states that mutual recognition is the aim, and that this could be gradually achieved. ${ }^{91}$ The first steps could be recognition of equivalence of regulations, focusing on the fact that they bring about an equivalent outcome, ie the same level of safety, environmental protection,

\footnotetext{
87 Art 6.3 TBT.

88 Mathis (n 75) 77.

89 ibid.

90 ibid 91.

91 Commission, 'Towards an EU-US Trade Deal. Making Trade Work For You'. The Transatlantic Trade and Investment Partnership (TTIP) Regulatory Issues: EU Position on Motor Vehicles (14 May 2014) <http://trade.ec.europa.eu/doclib/docs/2014/may/tradoc_152467. pdf $>$ accessed 7 July 2014, p 1.
} 
etc. ${ }^{92}$ This would be accompanied by closer cooperation in areas where there is no equivalence so as to create common rules. ${ }^{93}$ The field of motor vehicles might be specific due to the fact that there are existing agreements in this field, so other areas might require a different approach.

\section{Conclusion}

The EU on the one hand and the US and Canada on the other have a different level of risk aversion when it comes to risks to health, environment and animal welfare. The EU is more risk averse and adopts stricter rules to ensure a higher level of health, environment and animal welfare protection. This has created a number of obstacles to transatlantic trade and has led to WTO and other trade disputes.

Existing agreements which sought to address regulatory divergence, either within the framework of the WTO or separate bilateral instruments, have only achieved limited success. Currently negotiated comprehensive trade agreements, CETA and TTIP, also seek to enhance trade by removing non-tariff barriers caused by regulatory divergence. One cannot object to the removal of regulatory divergence which is a merely accidental consequence of the fact that regulators in two systems work independently of one another. However, in cases where there are true differences in the aims and values of two societies, regulatory divergence is positive from the perspective of diversity, pluralism, experimentation and democracy. Obstacles arising from such regulatory choices probably cannot and should not be removed by international agreements such as CETA or TTIP. It takes political effort, good surveys and intellectual honesty to selectively pin down which obstacles are of this latter type and ought to be maintained. Concerning the method of removing trade barriers, each of the possible mechanisms can politically and practically be difficult to achieve. While the equivalence and mutual recognition of conformity assessment procedures are already envisaged by WTO law, but do not do enough, and while harmonisation would be politically and practically most difficult and would (arguably) do too much, conditional mutual recognition of standards seems to impose itself as the middle way. Whether this mechanism of removing non-tariff trade barriers will be adopted in CETA and TTIP depends on how homogeneous the political actors see the North Atlantic space, and how far are they willing to take their relations.

92 ibid 1-2.

93 ibid 1,3 . 
